\title{
Sliding-Mode Based Idel Speed Control of an Automotive Engine
}

\author{
Umerujan Sawut Member (Nikki Co., Ltd.) \\ Kazushi Nakano Member (The University of Electro-Communications)
}

Keywords: engine modeling, throttle body, non-linear VSS observer, sliding-mode control

This paper presents an application of model-based control techniques to automotive engine speed control systems. There are three methods for controlling the engine speed: one is a method for controlling by air volume or throttle angle, the second by ignition timing, the third by fuel injection time. Use of the air volume is very effective when the engine speed is high and the differential variations of engine speed are small, but it is no longer effective because the response is so late due to the delay in air flow into the engine. Use of the ignition timing is effective for the differential variations of engine speed, but is invalid when the engine speed is high and the differential variations of engine speed are small. Use of the fuel injection time has different responses due to the variety of fuel supply piping and has negative effects on exhaust gas. Therefore, it has never been used.

We propose a method for controlling the engine speed using the throttle angle and ignition timing based on the errors between the measurement of engine speed and the desired one.

First, we build a mathematical model for automotive engine control systems shown in Fig. 1.

A model of the electronic-controlled throttle systems is described by

$$
\left[\begin{array}{c}
\dot{x}_{1} \\
\dot{x}_{2}
\end{array}\right]=\left[\begin{array}{c}
x_{2} \\
a_{1} x_{1}+a_{2} \operatorname{sgn}\left(x_{2}\right)+a_{3} x_{2}
\end{array}\right]+\left[\begin{array}{l}
b_{1} \\
b_{2}
\end{array}\right] U_{a}(t)
$$

where $x_{1}$ is the throttle angle, $x_{2}$ the throttle angular velocity, $a_{1}, a_{2}$, $a_{3}$ and $b_{1}, b_{2}$ the constants including physical parameters, and $U_{a}$ the input voltage. Secondly, a model of intake manifold systems is described as

$$
\left.\dot{P}_{(} t\right)=\frac{R T_{m}}{V}\left(\dot{m}_{a}(t)-\dot{m}_{c}(t)\right)
$$

where $P$ is the pressure in the manifold, $\dot{m}_{a}$ is the air mass flow rate into the manifold, and $\dot{m}_{c}$ is the air mass flow rate into the cylinder.

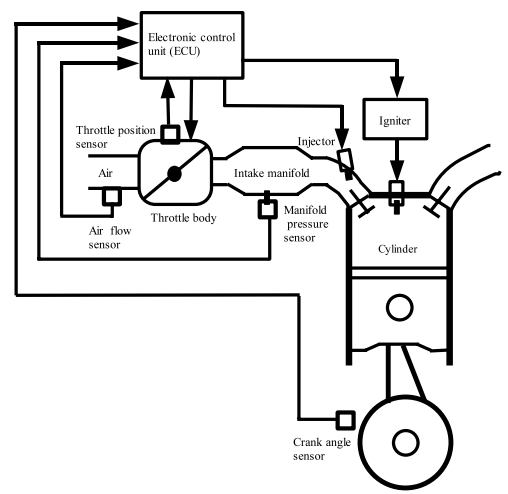

Fig. 1. Engine speed control system
Using the above model and the model of throttle systems, a model of engine rotating systems is described by

$$
\left.\dot{N}_{(} t\right)=\frac{30}{J_{a} \pi}\left(T_{I}(t)-T_{L}(t)\right)
$$

where $\dot{N}$ is the engine speed, and $T_{I}$ and $T_{L}$ are the engine torque and load torque, respectively.

The engine speed can be controlled by the throttle angle and ignition timing. The manipulated variable (input) is computed by the error between the engine speed, which can be measured by a crank sensor, and the desired one. An application of conventional PID control laws to such nonlinear engine control systems is invalid for the variation of the desired speed and system parameters. Therefore, we develop a new method of robust sliding-mode (SM) control using a nonlinear VSS observer. Our method makes it possible to determine the throttle angle and the ignition timing in engine control, which are different from conventional map-based methods:

$$
\begin{aligned}
& x_{d}(t)=\psi_{1} e_{n}(t)+\psi_{2} \dot{e}_{n}(t)+\psi_{3} \int e_{n}(t) d t \\
& \delta(t)=v_{1} e_{n}(t)+v_{2} \dot{e}_{n}(t)+v_{3} \int e_{n}(t) d t \\
& e_{n}(t)=N(t)-N_{d}
\end{aligned}
$$

where $x_{d}$ is the desired throttle angle, and $\delta$ is the ignition timing, and $\psi_{1}, \psi_{2}, \psi_{3}$ and $v_{1}, v_{2}, v_{3}$ are the constant design parameters.

The VSS observer and SM control system are designed by GA (genetic algorithm). The stability of the control systems can be guaranteed under the assumption that all the states can be perfectly estimated by the observer.

The simulation results demonstrate the effectiveness of our proposed method. Furthermore, almost the same experimental results as the simulation ones are shown in Fig. 2.

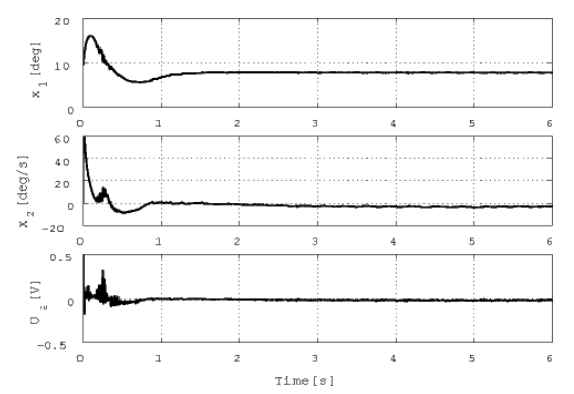

Fig. 2. Throttle angle, angular velocity and control input 


\title{
自動車エンジンのアイドリング回転数の スライディングモード制御
}

\author{
正 員 ウメルジャン サウット* 正 員 中野 和司**
}

Sliding-Mode Based Idel Speed Control of an Automotive Engine

\author{
Umerujan Sawut*, Member, Kazushi Nakano**, Member
}

\begin{abstract}
This paper presents an application of model-based control techniques to automotive engine speed control systems. Althougt the modeling of nonlinear systems has been carried out for automotive engines including electronic-controlled throttle servo systems, there still remains the difficulty of the strong non-linearity due to the engine friction and manifold pressure functions. This paper proposes a design method of some engine speed control by analyzing the nonlinear systems using sliding-mode control paradigm. In comparison with the map-based control method, the effectiveness of the proposed control method is verified using simulation and experimental results on an experimental system.
\end{abstract}

キーワード : エンジンモデル, スロットルボディ, 非線形 VSS オブザーバ, スライディングモード制御

Keywords: engine modeling, throttle body, non-linear VSS observer, sliding-mode control

\section{1. はじめに}

最近, 自動車用エンジンにおいては, 高トルクや高出力化 の要請とともに, 環境への対応がますます要求されている。 したがって, 燃費, 出力, 排気などのエンジンの性能を最 大に発揮させるために, 従来の気化器やディストリビュー 夕などの機械式制御機構が，電子制御システムに置き換え られており，またセンサやアクチュエータなどの急速な技 術革新に支えられ，今日ではモデルベース制御（MBC）シ ステムが主流をなしている。従来のエンジン回転数制御は マップ制御方式で行っていた。すなわち，エンジン回転数 がその目標回転数になるように空気流量や点火時期などを 実機実験にて調整し, そのときのエンジン回転数, マニホー ルド内圧力, 吸入空気温度およびスロットル開度など值を 記憶し，記憶されたデータをマップ化することによって制 御入力を決定する (1)(2)。その結果, マップのパラメータは実 験を繰り返しながら試行錯誤的に決定するため適合に時間 がかかる。また，エンジンやセンサ・アクチュエータなど の劣化に伴って制御性能が悪くなるなどの欠点がある。 本論文では，上述のような状況および従来のマップ制御

\footnotetext{
* (株) ニッキ

干 243-0801 厚木市上依知 3029 番地

Nikki Co., Ltd.

3029, Kamiechi, Atsugi 243-0801

** 電気通信大学

于 182-8585 調布市調布ケ丘 1-5-1

The University of Electro-Communications

1-5-1, Chofu-ga-oka, Chofu 182-8585
}

方式での問題を考慮し, 電子制御スロットルサーボ系を含 む自動車エンジン全体において, 非線形システムのモデリ ングとエンジン回転数制御を行うことにする。MBCの場 合は, 数学モデルをべースに制御系設計を行うので繰り返 し実験を行わなくてもシミュレーションで制御パラメータ を簡単に決定できる。従って，開発期間が大幅に短縮され る。エンジン回転数制御方法としては, 空気量（スロット ル開度）で制御する方法，点火時期で制御する方法と燃料 噴射時間で制御する方法がある。空気量で制御する場合, エンジン回転数が高くかつ回転数の変動が小さい場合には 有効であるが, 回転数の微分的な変動に対してエンジンに 吸い込まれる空気量の遅れがあるため応答性に劣る。点火 時期で制御する場合, 回転数の微分的な变動に対して非常 に有効であるが，回転数が高いかつ回転数の変動が小さい 場合あまり制御効果がない。燃料噴射時間で制御する場合, 燃料供給配管によって応答性が違い，また排気にも影響を 与えるため通常用いられない。

以上のような状況を考慮して, クランク角センサによっ て検出されたエンジン回転数とその目標エンジン回転数の 偏差に基づいて，スロットル開度および点火時期によって エンジン回転数制御を行う方法を提案する。この場合, エ ンジン回転数制御系は強度の非線形性を有するため, ロバ ストスライディングモード制御方法 ${ }^{(3)}$ を適用し, エンジン 回転数制御を行う。エンジン回転数制御においては, 負荷 変動なしとした場合とアイドリング時における負荷変動外 乱を加えた場合についてシミュレーションおよび実験を行 う。さらに従来のマップ制御との比較を行い, 提案する制 
御法の有効性を確認する。

\section{2. エンジン制御システムのモデル}

本研究の自動車用エンジン制御システムにおいて, 制御 対象とするシステム概要を図 1 に示す。電子制御ユニット (Electronic Control Unit：ECU) は，アクセル開度センサに よるペダルストローク信号，および各種センサの入力信号 などにより演算処理を行い，スロットルバルブの開度指示 を出力する。またアクチュエータである電子制御スロット ルバルブシステムにおいては，ECUの演算結果に基づき， 駆動モータによりスロットル開度が目標開度に追従するよ う制御され，最終的にスロットルを通過する吸入空気量が 制御される。スロットルを通過した吸入空気は，インテー クマニホールド内圧力とシリンダ内圧力の差圧によりシリ ンダ内に吸い达まれる。ここでは，まず始めに，電子制御 スロットルシステムのモデル化と吸気系のモデル化を行い, 次にそれらのモデリング結果を用いて，エンジン回転系全 体のモデル化を行う。

〈2・1〉 スロットルシステムのモデル＼cjkstart電子制御スロ ットルシステムについての数学モデルを次のように考え る (3) (7)。まず，スロットルの駆動部分である直流モー夕の 電気的な特性を考える。電機子回路における電機子電流と 電圧の関係はキルヒホッフの法則に従い, 次式でモデル化 される。

$$
L_{a} \frac{d i_{a}}{d t}+R_{a} i_{a}+K_{e} N_{g} \frac{d \theta}{d t}=U_{a}
$$

ここに, $i_{a}$ は電機子電流, $U_{a}$ は電機子両端の入力電圧, $L_{a}$ と $R_{a}$ は電機子のインダクタンスと抵抗， $K_{e}$ は誘起電圧定 数, $N_{g}$ はギヤ比, $\theta$ はスロットル角度である。一方, モー タのトルク定数を $K_{t}$ とすれば，電機子に加わる電磁的な卜 ルクは $T=K_{t} i_{a}$ となるから, 電子制御スロットルシステム の運動方程式は次式のように求められる。

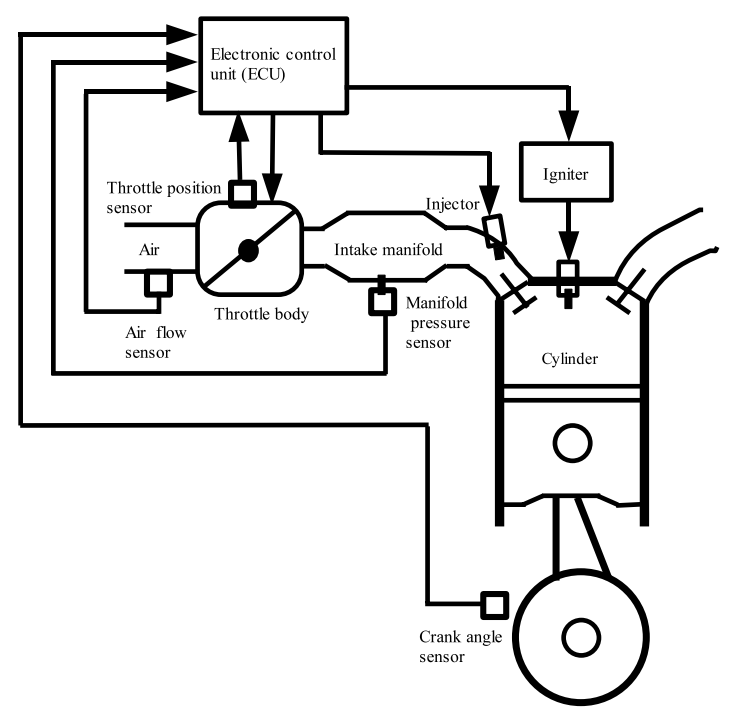

図 1 エンジン速度制御システム

Fig. 1. Engine speed conrtol systems.

$$
J \frac{d^{2} \theta}{d t^{2}}+D \frac{d \theta}{d t}+d_{k} \operatorname{sgn}\left(\frac{d \theta}{d t}\right)+K_{s} \theta=N_{g} K_{t} i_{a} \ldots \ldots
$$

ここに, $J$ は系のスロットル軸換算の全慣性モーメント, $D$ は粘性摩擦係数, $d_{k}$ はクーロン摩擦, $K_{s}$ はリターンスプリ ングのばね定数である。電機子のインダクタンス成分 $L_{a}$ は 無視できるとして，(1) 式を(2) 式に代入すると次式を得る。

$$
\begin{aligned}
\ddot{\theta}= & -\frac{1}{J}\left(D+\frac{N_{g}^{2} K_{t} K_{e}}{R_{a}}\right) \dot{\theta} \\
& -\frac{1}{J} d_{k} \operatorname{sgn}(\dot{\theta})-\frac{1}{J} K_{s} \theta+\frac{N_{g} K_{t}}{R_{a} J} U_{a}
\end{aligned}
$$

(3) 式において, 状態変数 $x_{1}=\theta, x_{2}=\dot{\theta}$ とおくと, システ 厶の状態方程式と出力方程式は次のように求められる。

$$
\begin{aligned}
{\left[\begin{array}{c}
\dot{x}_{1} \\
\dot{x}_{2}
\end{array}\right]=} & {\left[\begin{array}{c}
x_{2} \\
a_{1} x_{1}+a_{2} \operatorname{sgn}\left(x_{2}\right)+a_{3} x_{2}
\end{array}\right] } \\
& +\left[\begin{array}{l}
b_{1} \\
b_{2}
\end{array}\right] U_{a} \ldots \ldots \ldots \ldots \ldots \ldots
\end{aligned}
$$

$y=x_{1}$

上記の状態方程式と出力方程式において,

$$
\begin{aligned}
& a_{1}=-\frac{K_{s}}{J} \\
& a_{2}=-\frac{d_{k}}{J} \\
& a_{3}=-\left(\frac{D}{J}+\frac{N_{g}^{2} K_{t} K_{e}}{R_{a} J}\right) \\
& b_{1}=0 \\
& b_{2}=\frac{N_{g} K_{t}}{R_{a} J}
\end{aligned}
$$

であり $y$ ははスロットル角の観測值である。

$\langle\mathbf{2} \cdot \mathbf{2}\rangle$ 吸気系のモデル エンジンの吸入空気量は, 燃 料の基本噴射量を決定するための極めて重要なパラメータ の一つであり，これにより的確な空然比制御が可能となる。 また吸入空気量の計量は, 吸気管の絞り弁上流に配置され た渦流系などの流量計により，単位時間当たりの空気量と して算出されるのが一般的である。しかし，このような計 量方法では, 空気の密度補正が必要となり, かつ, 吸気管 の長さや形状が異なった場合には実際にシリンダ内に吸入 される空気量を正確に見積ることが困難となる。そのため, 特に過渡運転などのエンジン運転条件では, 燃料噴射量を 正確に制御することは容易ではない。したがって，シリン ダに実際に吸入される空気量の推定が必要となる。

スロットルを通過してインテークマニホールドへ導かれ る空気の質量流量は, スロットル開度のみからなる関数と, 大気圧とマニホールド内圧力からなる二つの関数より, 次 のように求められる ${ }^{(8) \sim(11)}$ 。

$$
\dot{m}_{a}=f\left(x_{1}\right) g(P)
$$
ここで，

$$
f\left(x_{1}\right)=k_{m}\left(j_{1}+j_{2} x_{1}+j_{3} x_{1}^{2}-j_{4} x_{1}^{3}\right)
$$




$$
\begin{aligned}
& g(P)= \begin{cases}1 & \text { if } P \leq \frac{P_{a}}{2} \\
\frac{2}{P_{a}} \sqrt{P P_{a}-P^{2}} & \text { if } \frac{P_{a}}{2} \leq P \leq P_{a} \\
-\frac{2}{P} \sqrt{P P_{a}-P_{a}^{2}} & \text { if } P_{a} \leq P \leq 2 P_{a} \\
-1 & \text { if } P \geq 2 P_{a}\end{cases} \\
& \dot{m}_{a}: \text { マニホールドへ導かれる空気の質量流量 } \\
& P: \text { マニホールド内压力 } \\
& P_{a}: \text { 大気圧力 } \\
& j_{1} \sim j_{4}: \text { 定数 } \\
& k_{m}: \text { 定数 }
\end{aligned}
$$

である。

一方，マニホールド内からシリンダ内への空気の質量流 量は, エンジン回転数と, マニホールド内圧力により, 次 式のように求めることができる。

$$
\dot{m}_{c}=-c_{1} N-c_{2} P+c_{3} N P+c_{4} N P^{2}
$$

したがって，吸気系のモデルは，(6) 式と (9) 式を用い，マ ニホールド内圧力に対する微分方程式により，次のように 求められる(8)(9)。

$$
\dot{P}=\frac{R T_{m}}{V}\left(\dot{m}_{a}-\dot{m}_{c}\right)
$$

ただし，

$$
\begin{aligned}
& \dot{m}_{c}: \text { シリンダへの空気質量流量 } \\
& N: \text { エンジン回転数 } \\
& c_{1} \sim c_{4}: \text { 定数 } \\
& R: \text { 気体定数 } \\
& T_{m}: \text { マニホールド内の温度 } \\
& V: \text { マニホールド容積 }
\end{aligned}
$$

である。

〈2·3〉 エンジン回転系のモデル＼cjkstart本節では，スロッ トルシステム拈よび吸気系のモデリング結果をエンジン回 転系に組み込み，エンジン回転系全体のモデリングを行う。 エンジンの回転運動方程式は, 運動部の慣性モーメント, エ ンジン回転数，エンジントルク，負荷トルクおよび点火時 期より次式で表される(8)(9)。

$$
\dot{N}=\frac{30}{J_{e} \pi}\left(T_{i}-T_{l}\right)
$$

ただし，

$$
\begin{aligned}
T_{i}= & -k_{1}+k_{2} \frac{\dot{m}_{c}}{N}+k_{3} \delta+k_{4} N \delta \\
& -k_{5} \delta^{2}+k_{6} N-k_{7} N^{2} \ldots \\
T_{l}= & \beta N^{2}+T_{d} \ldots \ldots \ldots \ldots \ldots
\end{aligned}
$$

であり， $J_{e}$ は運動部の慣性モーメント, $T_{i}$ はエンジントル ク， $T_{l}$ は負荷トルク， $T_{d}$ はアクセサリートルク， $k_{1} \sim k_{7}$ は 定数, $\beta$ は定数, $\delta$ は点火時期であり, これは後述される (15) 式によって計算される。

\section{3. 制御系の設計}

エンジン回転数制御システムにおいては，エンジン回転 数はスロットル角度および点火時期で制御され，その操作 量はクランクセンサによって観測されたエンジン回転数と 目標回転数の偏差に基づいて計算される。非線形特性を有 するエンジンシステムに対して, 従来の PID 制御の適用が 困難である。例えば PID 制御では，目標值やシステムパラ メータなどが変動した場合は，同じ制御パラメータで制御 を行うことが困難であるため P， I，D ゲインも同時に変化 させなければならないなどの欠点がある。あるいは，ほか に補正回路などの設計が必要となる。それらの問題に対し て,ここではエンジン回転数制御に非線形VSS オブザーバ を用いたロバストスライディングモード制御を適用する方 法を提案する。スライディングモード制御のロバスト性は, 最もきわだった特性の一つである。線形または非線形の高 次微分方程式で表されたプラントに対して，スライディン グモード超平面の微分方程式は, マッチング条件のもとで システムのモデル化誤差と外生入力（外乱）から完全に独 立とすることができる。このようにスライデイングモード はシステムのモデル化誤差や外乱などに対してロバストで あるため, 線形系はもちろん非線形系, パラメー夕変動系, 時変系など，未知パラメータや未知外乱を有する系に容易 に適用できる(12)。エンジン回転数を目標回転数に最短時間 で到達させるには，スロットル角度と点火時期が，それぞ れの目標值に同時に到達するように制御されなくてはなら ない。ここでは，まず目標スロットル角度および点火時期 制御アルゴリズムについて述べ，次にスロットルを最短時 間で目標角度に到達させるスロットル制御アルゴリズムに ついて述べる。

〈3・1〉 目標スロットル角度および点火時期制御アルゴ リズム従来のエンジン制御では目標スロットル角度, 点火時期などはすべてマップ方式で求めたものであり，エ ンジン回転数制御も空気量のみで制御されたものである。 しかし, 車両の走行距離㧍よび部品の劣化に従ってマップ 方式で求めたものでは合わなくなり, 制御性能も悪化する など問題がある。以上のような状況を考慮して, クランク センサによって観測されたエンジン回転数と目標回転数の 偏差に基づいて, 目標スロットル角度を計算し, エンジン 回転数が目標エンジン回転数になるように，スロットル角 度拧よび点火時期を制御する方法を提案する。

(11) 式の非線形システムにおいて目標值との偏差を $e_{n}(t)=$ $N(t)-N_{d}$ とし, 目標スロットル角度 $x_{d}(t)$ を次のように求 める。

$$
x_{d}(t)=\psi_{1} e_{n}(t)+\psi_{2} \dot{e}_{n}(t)+\psi_{3} \int e_{n}(t) d t .
$$

ただし， $\psi_{1} \sim \psi_{3}$ はそれぞれ定数である。同様に，点火時期 制御アルゴリズムは次のように計算される。

$$
\delta(t)=v_{1} e_{n}(t)+v_{2} \dot{e}_{n}(t)+v_{3} \int e_{n}(t) d t
$$


ここに， $v_{1} \sim v_{3}$ はそれぞれ定数である。

〈3・2〉 非線形 VSS オブザーバの設計ここでは，(5) 式のようにシステムの状態のうちスロットル角度しか測定 できないとする。このようなスロットル角度のみのフィー ドバックでは制御性能において不十分であるため, ここで すべての状態量を推定する機能をもつ状態オブザーバを設 計する。まず，(4) 式と (5) 式を次式のように書き直す。

$$
\begin{aligned}
& \dot{\boldsymbol{x}}=f(\boldsymbol{x})+\boldsymbol{b} U_{a} \\
& y=\boldsymbol{c}^{T} \boldsymbol{x} \ldots \ldots
\end{aligned}
$$

ここで，状態べクトル $\boldsymbol{x}$ を次のように定義する。

$$
\boldsymbol{x}=\left[\begin{array}{ll}
x_{1} & x_{2}
\end{array}\right]^{T}
$$

また，

$$
f(\boldsymbol{x})=\left[\begin{array}{c}
x_{2} \\
a_{1} x_{1}+a_{2} \operatorname{sgn}\left(x_{2}\right)+a_{3} x_{2}
\end{array}\right]
$$

であり, $\boldsymbol{b}=\left[\begin{array}{ll}b_{1} & b_{2}\end{array}\right]^{T}, \boldsymbol{c}=\left[\begin{array}{ll}1 & 0\end{array}\right]^{T}$ である。

この非線形系に対して, 下記のようなシステムの全状態 量を推定するロバストVSS オブザーバを設計する(13)(14)。

$$
\begin{aligned}
& \dot{\hat{\boldsymbol{x}}}=f(\hat{\boldsymbol{x}})+\boldsymbol{b} U_{a}+\boldsymbol{b} \zeta \operatorname{sgn}(\bar{y})+\boldsymbol{k}_{\boldsymbol{g}} \bar{y} \cdot \\
& \bar{y}=\hat{y}-y=\boldsymbol{c}^{T}(\hat{\boldsymbol{x}}-\boldsymbol{x}) \ldots \ldots \ldots \ldots
\end{aligned}
$$

ここに

$$
\operatorname{sgn}(\bar{y})= \begin{cases}1 & \text { if } \bar{y}>0 \\ 0 & \text { if } \bar{y}=0 \\ -1 & \text { if } \bar{y}<0\end{cases}
$$

であり, $\hat{\boldsymbol{x}}$ はシステム状態の推定值を表し, $\boldsymbol{k}_{\boldsymbol{g}}=\left[\begin{array}{ll}k_{g 1} & k_{g 2}\end{array}\right]^{T}$ はオブザーバゲイン行列, $\boldsymbol{b} \zeta \operatorname{sgn}(\bar{y})$ はオブザーバの非線 形補償入力項, らはスカラゲインである。推定誤差を

$$
e_{o}=\hat{x}-x
$$

とおくと，誤差システムは次のようになる。

$$
\begin{aligned}
\dot{\boldsymbol{e}_{\boldsymbol{o}}}= & f(\hat{\boldsymbol{x}})-f(\boldsymbol{x})+\boldsymbol{k}_{\boldsymbol{g}} \boldsymbol{c}^{T} \boldsymbol{e}_{\boldsymbol{o}} \\
& +\boldsymbol{b} \boldsymbol{c}^{T} \zeta \operatorname{sgn}\left(\boldsymbol{c}^{T} \boldsymbol{e}_{\boldsymbol{o}}\right) \cdots
\end{aligned}
$$

オブザーバゲイン $\boldsymbol{k}_{\boldsymbol{g}}$ は (24) 式が安定となるように決定す ることができる。その結果, $\boldsymbol{k}_{\boldsymbol{g}}=\left[\begin{array}{ll}-185 & 0.152\end{array}\right]^{T}, \zeta=1.25$ となる。この詳細については文献(3) を参照されたい。

〈3·3〉 スライディングモード制御系の設計オブザー バによる状態変数の推定值を用いて, (16) 式の非線形シス テムにおいて目標值との誤差を $e_{c}(t)=\boldsymbol{c}^{T}\left(\hat{\boldsymbol{x}}(\boldsymbol{t})-\boldsymbol{x}_{\boldsymbol{d}}\right)$ とし, スライディング切換え超平面を次式のように定める ${ }^{(14)(15)}$ 。

$$
\sigma(t)=s_{1} e_{c}(t)+s_{2} \dot{e}_{c}(t)+s_{3} \int e_{c}(t) d t
$$

ここに, $s_{1} \sim s_{3}$ は定数であり, 後述される方法で決定され る。次に, この超平面に状態を常に拘束させるために非線
形入力であるスライディングモードコントローラの設計を 行う。スライディングモードを生じるとき

$$
\begin{aligned}
& \sigma(t)=0 \ldots \ldots \ldots \ldots \ldots \ldots \ldots \ldots \ldots \ldots \\
& \dot{\sigma}(t)=s_{1} \dot{e}_{c}(t)+s_{2} \ddot{e}_{c}(t)+s_{3} e_{c}(t)=0
\end{aligned}
$$

となるので，(20) 式と (27) 式よりスライディングモード制 御入力を次のように設計する ${ }^{(14)(15)}$ 。

$$
\begin{aligned}
U_{a}= & \varepsilon\left\{\left(-s_{1} \dot{e}_{c}-s_{2}\left(a_{1} \hat{x}_{1}+a_{2} \operatorname{sgn}\left(\hat{x}_{2}\right)\right.\right.\right. \\
& \left.\left.\left.+a_{3} \hat{x}_{2}\right)-s_{3} e_{c}\right) \frac{1}{s_{2} b_{2}}-F \operatorname{sgn}(\sigma)\right\}
\end{aligned}
$$

ここに

$$
\begin{gathered}
F=\lambda \mid-s_{1} \dot{e}_{c}+s_{2}\left(a_{1} \hat{x}_{1}+a_{2} \operatorname{sgn}\left(\hat{x}_{2}\right)\right. \\
\left.\quad+a_{3} \hat{x}_{2}\right)-s_{3} e_{c} \mid+\eta \ldots \ldots \ldots \ldots \\
\operatorname{sgn}(\sigma)= \begin{cases}1 & \text { if } \sigma>0 \\
0 & \text { if } \sigma=0 \\
-1 & \text { if } \sigma<0\end{cases}
\end{gathered}
$$

$\eta>0, \varepsilon>0, \lambda>0$ である。切換え超平面に関するリアプ ノフ関数の候補を次のように選ぶ。

$$
V=\frac{1}{2} \sigma^{2}
$$

すると, その時間微分は

$$
\begin{aligned}
& \dot{V}=\sigma \dot{\sigma}=\sigma\left(s_{1} \dot{e_{c}}+s_{2} \dot{\hat{x}}_{2}+s_{3} e_{c}\right) \\
& =\sigma\left\{s_{1} \dot{e}_{c}+s_{2}\left(a_{1} \hat{x}_{1}+a_{2} \operatorname{sgn}\left(\hat{x}_{2}\right)\right.\right. \\
& \left.\left.+a_{3} \hat{x}_{2}+b_{2} U_{a}+b_{2} \zeta \operatorname{sgn}(\bar{y})+k_{g 2} \bar{y}\right)+s_{3} e_{c}\right\} \\
& =\sigma\left\{s_{1} \dot{e}_{c}+s_{2}\left(a_{1} \hat{x}_{1}+a_{2} \operatorname{sgn}\left(\hat{x}_{2}\right)+a_{3} \hat{x}_{2}\right)\right. \\
& +s_{3} e_{c}+\varepsilon\left\{-s_{1} \dot{e}_{c}-s_{2}\left(a_{1} \hat{x}_{1}+a_{2} \operatorname{sgn}\left(\hat{x}_{2}\right)\right.\right. \\
& \left.\left.+a_{3} \hat{x_{2}}\right)-s_{3} e_{c}\right\}-\varepsilon s_{2} b_{2} F \operatorname{sgn}(\sigma) \\
& \left.+s_{2} b_{2} \zeta \operatorname{sgn}(\bar{y})+s_{2} k_{g 2} \bar{y}\right\} \\
& =\sigma\left\{( 1 - \varepsilon ) \left(s_{1} \dot{e}_{c}+s_{2}\left(a_{1} \hat{x}_{1}+a_{2} \operatorname{sgn}\left(\hat{x}_{2}\right)\right.\right.\right. \\
& \left.\left.+a_{3} \hat{x}_{2}\right)+s_{3} e_{c}\right)-\varepsilon s_{2} b_{2} F \operatorname{sgn}(\sigma) \\
& \left.+s_{2} b_{2} \zeta \operatorname{sgn}(\bar{y})+s_{2} k_{g 2} \bar{y}\right\}
\end{aligned}
$$

となる。それで, 前節で設計したオブザーバが安定に動作 していると仮定し $(\bar{y}=0), \eta, \varepsilon, \lambda, \alpha$ の定義および (32) 式より $(\varepsilon+\alpha \lambda)>1$ となるように $\eta, \varepsilon, \lambda, \alpha$ を決定すれ ば，(32) 式を次のように書き直すことができる。ただし， $\alpha=\varepsilon s_{2} b_{2}$ である。

$$
\begin{aligned}
\dot{V}= & \sigma\left\{( 1 - \varepsilon ) \left(s_{1} \dot{e}_{c}+s_{2}\left(a_{1} \hat{x}_{1}+a_{2} \operatorname{sgn}\left(\hat{x}_{2}\right)\right.\right.\right. \\
& \left.\left.+a_{3} \hat{x}_{2}\right)+s_{3} e_{c}\right)-\alpha \lambda \mid-s_{1} \dot{e}_{c}-s_{2}\left(a_{1} \hat{x}_{1}\right. \\
& \left.+a_{2} \operatorname{sgn}\left(\hat{x}_{2}\right)+a_{3} \hat{x}_{2}\right)-s_{3} e_{c} \mid \operatorname{sgn}(\sigma) \\
& -\alpha \eta \operatorname{sgn}(\sigma)\} \leq-\eta|\sigma| \ldots \ldots \ldots \ldots \ldots
\end{aligned}
$$

以上により， $\dot{V}<0$ となり安定なスライディングモード制 御を実現できる。また, チャタリングを除去するため, 通 
常よく行われるように sgn 関数の代りに飽和関数 $\operatorname{sat}(\sigma / \phi)$ を用いた。この詳細についても文献(3) を参照されたい。 制御パラメータは遺伝的アルゴリズム $(\mathrm{GA})$ を用いて次 の評価関数を最小にするように決定される ${ }^{(14) \sim(16)}$ 。

$$
J_{j}=\int_{0}^{T_{j}} \mid\left(\hat{x}(t)-x_{d}(t) \mid d t\right.
$$

GA においては，決定すべきパラメータ $s_{1}, s_{2}, s_{3}, \varepsilon, \lambda, \eta$, $\phi$ は，それぞれ 12 ビットの二進数で表現する。したがって， それらは 84 ビット長の個体とし, 個体数 30 の母集団を構 成した。選択交叉はルーレット方式, 一点交叉, 突然変異確 率 $0.025, T_{j}=5.0[\mathrm{~s}]$ とし, 適応度関数として (34) 式の逆 数を用いた。ただし，スライディングモード平面を表すパ ラメータは，制御系が必ず安定となるようにパラメータの 変化範囲を設定した。その結果, 100 世代後に, $s_{1}=1.235$, $s_{2}=0.102, s_{3}=2.52, \varepsilon=1.218, \lambda=2.68, \quad \eta=0.0001$, $\phi=0.45$ が得られた。

\section{4. シミュレーションおよび実験結果}

エンジンアイドリング回転数制御において，提案する方 法の有効性を確認，検討するため，スライディングモード 制御によりシミュレーションおよび実機実験を行った。さ らに，アイドリング時における負荷変動外乱に対するロバ スト性を確認，検討するため実機実験を行った。また，従 来のマップ制御方式と比較検討も行った。

実験には直列 6 気筒 $2.5 \mathrm{~L}$ エンジンを使用した。シミュ レーションおよび実験において, 入出力信号のサンプリン グ周期 $\Delta t=1.0[\mathrm{~ms}]$, 始動時水温を $20\left[{ }^{\circ} \mathrm{C}\right]$, エンジン回 転数の初期值を $N_{0}=200[\mathrm{rpm}]$ ，スロットルの初期状態を $\boldsymbol{x}_{\mathbf{0}}=\left[\begin{array}{ll}5 & 0\end{array}\right]^{T}$, 目標エンジン回転数をアイドリング時におい て $800[\mathrm{rpm}]$ とする。ほかの設計パラメータは表 1 のとお りである (3) ( (9)。

〈4・1〉 シミュレーション結果および検討 エンジン回 転数制御においてのシミュレーション結果をそれぞれ図 2 , 図 3, 図 4 に示す。図 2 は, スロットル角度, 角速度, お よび制御入力をそれぞれ示している。図 3 は，スロットル

表 1 エンジン制御システムのパラメータ

Table 1. Parameters of engine control systems.

\begin{tabular}{c|c|c|c}
\hline symbols & values & symbols & values \\
\hline$a_{1}$ & $-1.503 \times 10^{1}$ & $k_{2}$ & $2.667 \times 10^{5}$ \\
$a_{2}$ & -0.297 & $k_{3}$ & 0.830 \\
$a_{3}$ & $-1.312 \times 10^{1}$ & $k_{4}$ & 0.052 \\
$b_{2}$ & $6.820 \times 10^{2}$ & $k_{5}$ & 0.765 \\
$i_{1}$ & $0.112 \times 10^{1}$ & $k_{6}$ & 0.056 \\
$i_{2}$ & 0.915 & $k_{7}$ & $0.572 \times 10^{-4}$ \\
$i_{3}$ & 0.106 & $\beta$ & $0.420 \times 10^{-2}$ \\
$i_{4}$ & 0.002 & $\psi_{1}$ & 0.120 \\
$k_{m}$ & 1.219 & $\psi_{2}$ & 0.023 \\
$c_{1}$ & 0.001 & $\psi_{3}$ & 0.005 \\
$c_{2}$ & $0.505 \times 10^{-1}$ & $v_{1}$ & 0.250 \\
$c_{3}$ & $0.086 \times 10^{-2}$ & $v_{2}$ & 0.014 \\
$c_{4}$ & $0.012 \times 10^{-5}$ & $v_{3}$ & 0.003 \\
$k_{1}$ & $1.756 \times 10^{1}$ & & \\
\hline
\end{tabular}

を通過してインテークマニホールド内に導かれる空気の質 量流量，マニホールドからシリンダへ導かれる空気の質量 流量，および点火時期をそれぞれ示している。図 4 は，マ ニホールド内圧力，およびエンジン回転数を示している。

シミュレーション結果から, エンジン回転数, スロット ル角度および制御入力ともにチャタリングを起こさず，目 標值に収束していることがわかる。したがって, 状態変数 はスライディングモードに収束し, 設計したスライディン グモード制御は安定に動作していることが確認された。

〈4・2〉 実験結果および検討 エンジン回転数制御にお いて負荷変動なしと考えた場合の実験結果をそれぞれ図 5, 図 6, 図 7 に示す。図 5 は, スロットル角度, 角速度, お よび制御入力をそれぞれ示している。図 6 は，スロットル を通過してインテークマニホールド内に導かれる空気の質 量流量, マニホールドからシリンダへ導かれる空気の質量 流量, および点火時期をそれぞれ示している。図 7 は, マ ニホールド内圧力，およびエンジン回転数を示している。
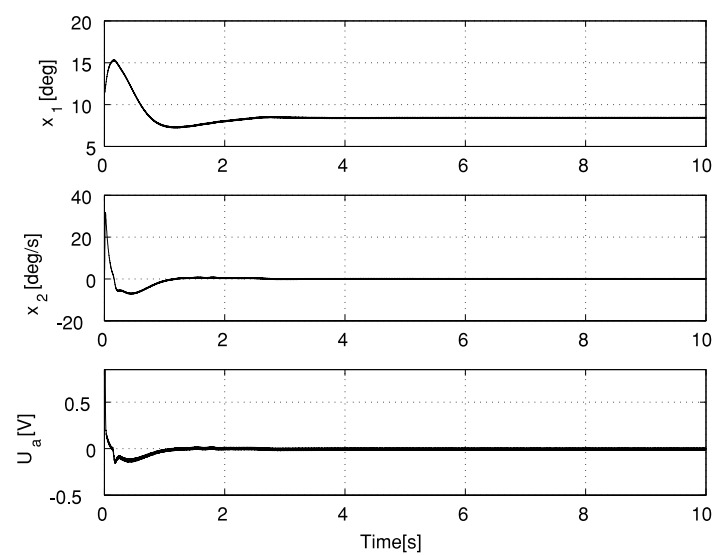

図 2 スロットル角，角速度，制御入力

Fig. 2. Throttle angle, angular velocity and control input.
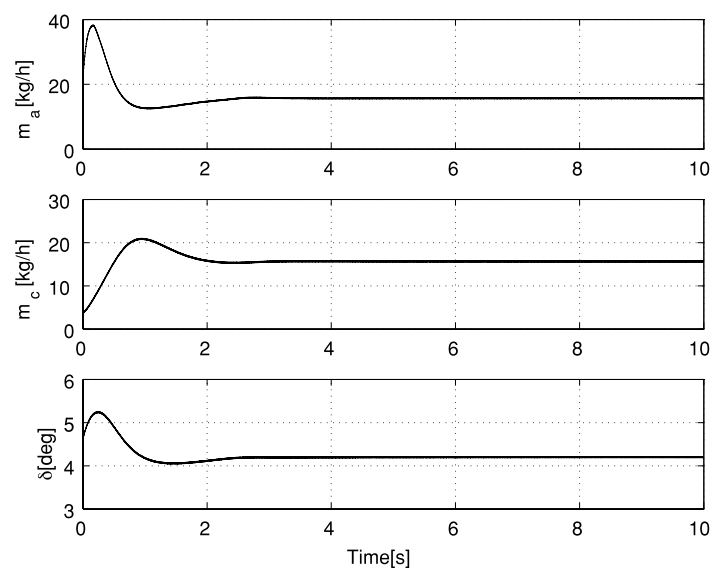

図 3 インテークマニホールド内に導かれる 空気の質量流量, シリンダへ導かれる空気の 質量流量，点火時期

Fig. 3. Mass flow rate into manifold, mass flow rate into cylinder and spark advance. 

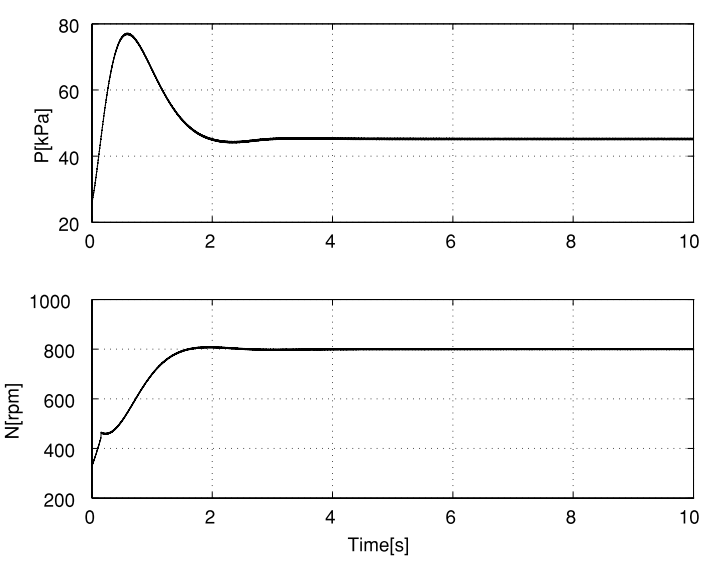

図 4 マニホールド内圧力とエンジン回転数

Fig. 4. Manifold pressure and engine speed.
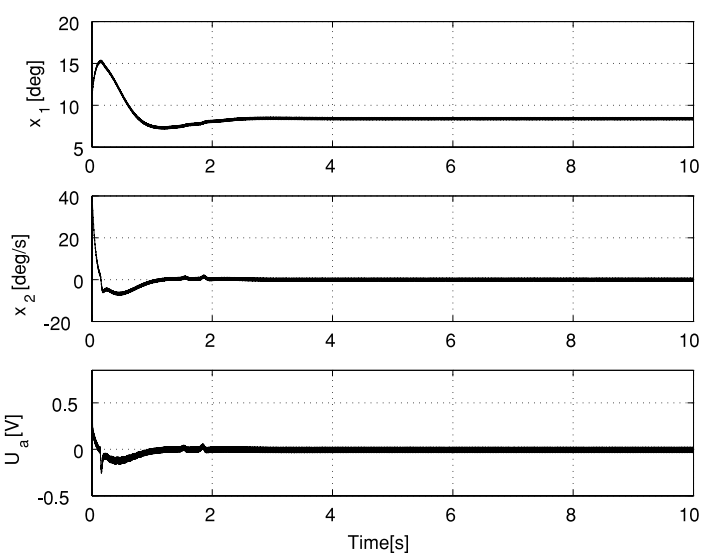

図 5 スロットル角, 角速度, 制御入力

Fig. 5. Throttle angle, angular velocity and control input.
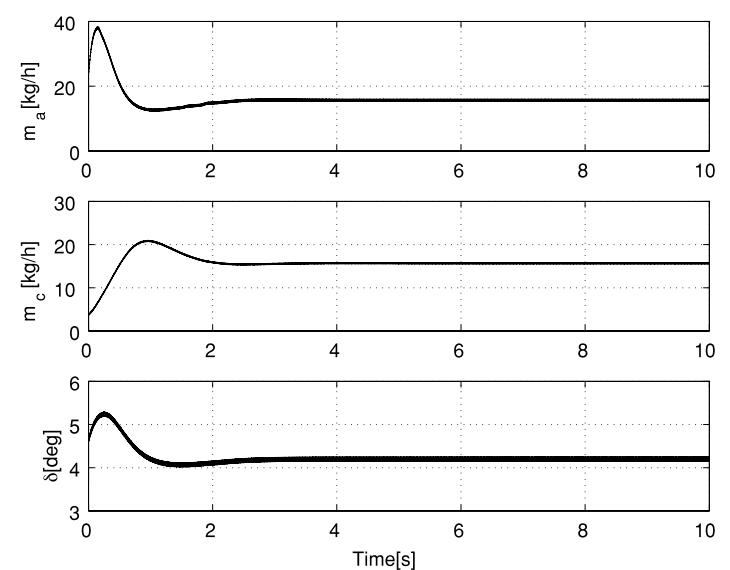

図 6 インテークマニホールド内に導かれる 空気の質量流量, シリンダへ導かれる空気の 質量流量，点火時期

Fig. 6. Mass flow rate into manifold, mass flow rate into cylinder and spark advance.

これらの実験結果は, シミュレーション結果とほぼ一致 しており，与えられた目標回転数に対して，制御量が定常誤 差なく追従していることがわかる。一方，従来のマップ制
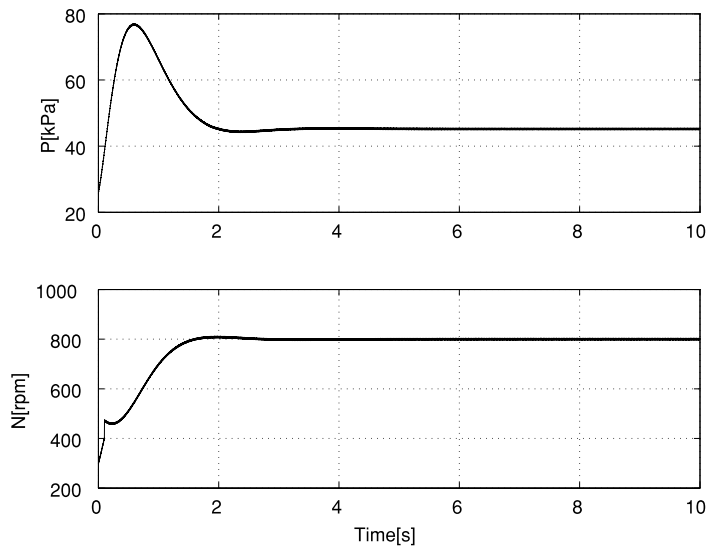

図 7 マニホールド内圧力とエンジン回転数

Fig. 7. Manifold pressure and engine speed.
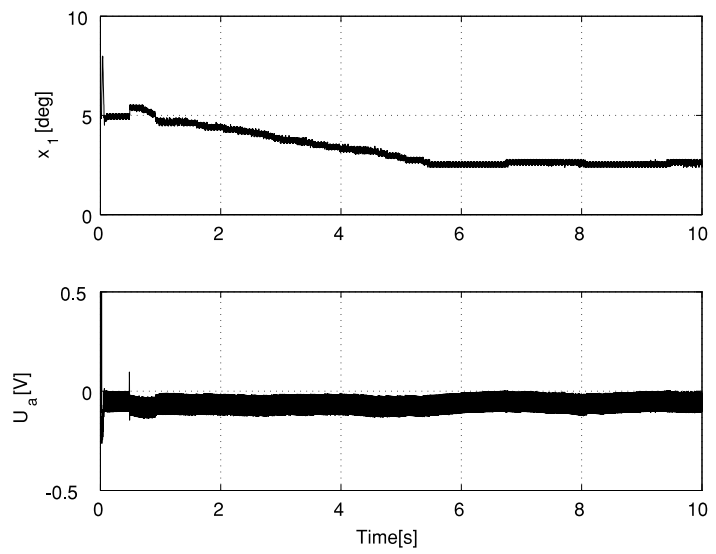

図 8 スロットル角と制御入力

Fig. 8. Throttle angle and control input
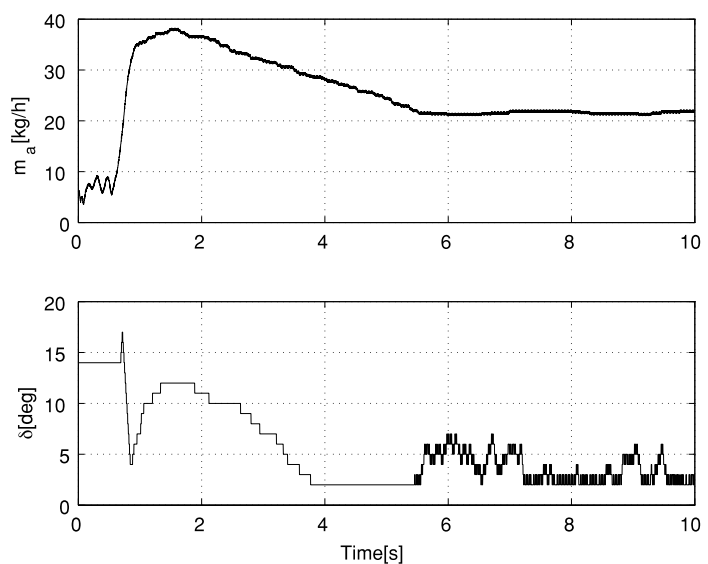

図 9 インテークマニホールド内に導かれる空気 の質量流量と点火時期

Fig. 9. Mass flow rate into the manifold and spark advance

御方式を用いた場合の実験結果をそれぞれ図 8, 図 9, 図 10 に示す。図 8 は，スロットル角度および制御入力をそれぞ れ示している。図 9 は, スロットルを通過してインテーク マニホールド内に導かれる空気の質量流量および点火時期 

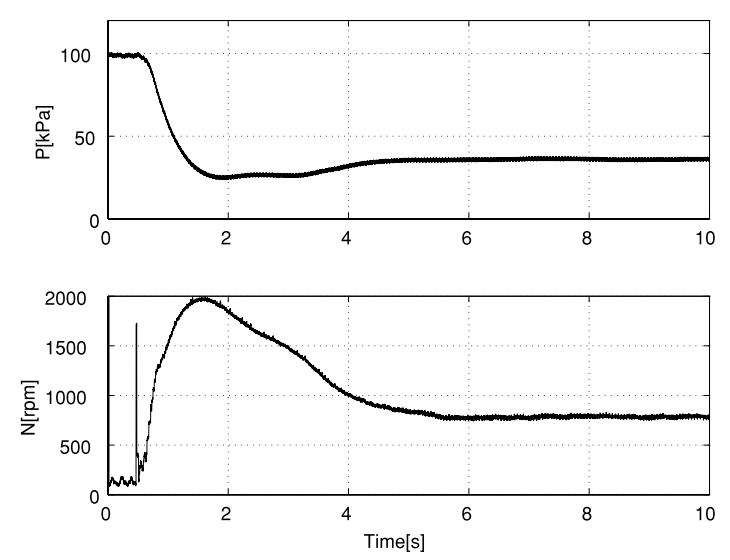

図 10 マニホールド内圧力とエンジン回転数

Fig. 10. Manifold pressure and engine speed
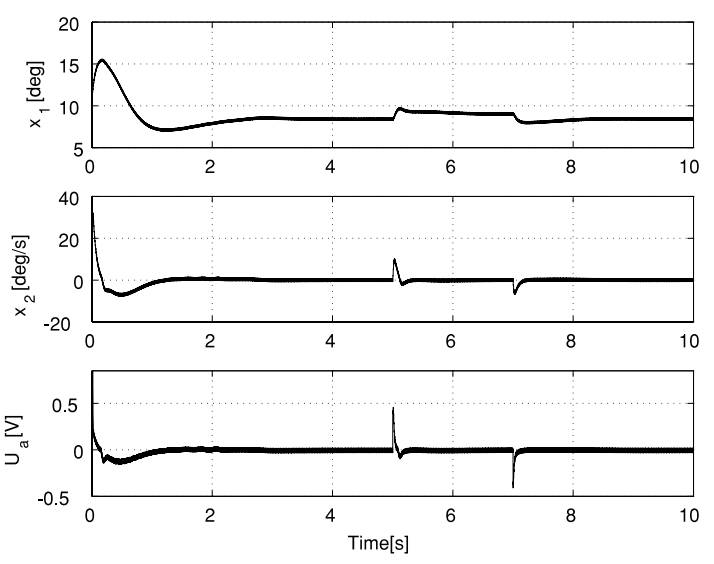

図 11 スロットル角, 角速度, 制御入力

Fig. 11. Throttle angle, angular velocity and control input.

をそれぞれ示している。図 10 は，マニホールド内圧力，お よびエンジン回転数を示している。なお，マップ制御方法 ではスロットル角速度，マニホールドからシリンダへ導か れる空気の質量流量などの推定は行っていない。

マップ制御法の実験結果から，提案の MBCのほうが与 えられた目標值に対して，オーバーシュートもなく速く収 束していることがわかる。

アイドリング時における負荷変動外乱（ギヤを N レンジ からDレンジに切換え) に対する実験結果をそれぞれ図 11， 図 12, 図 13 に示す。図 11 は, スロットル角度, 角速度, および制御入力をそれぞれ示している。図 12 は，スロット ルを通過してインテークマニホールド内に導かれる空気の 質量流量，マニホールドからシリンダへ導かれる空気の質 量流量，および点火時期をそれぞれ示している。図 13 は,

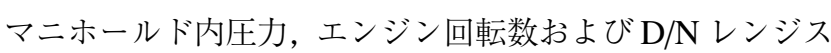
イッチを示している。

実験結果から，本手法は外乱に対しても有効であること がわかる。従って，シミュレーションおよび実験結果が比 較的によく一致している打り，提案したモデリングおよび 制御手法の有効性が確認できた。さらに，VSS オブザーバ
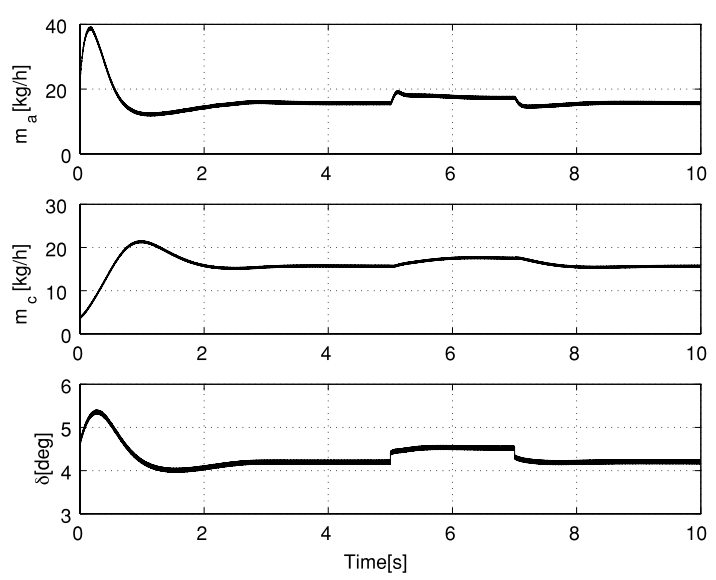

図 12 インテークマニホールド内に導かれる 空気の質量流量, シリンダへ導かれる空気の

質量流量と, 点火時期

Fig. 12. Mass flow rate into the manifold, mass flow rate into the cylinder and spark advance.
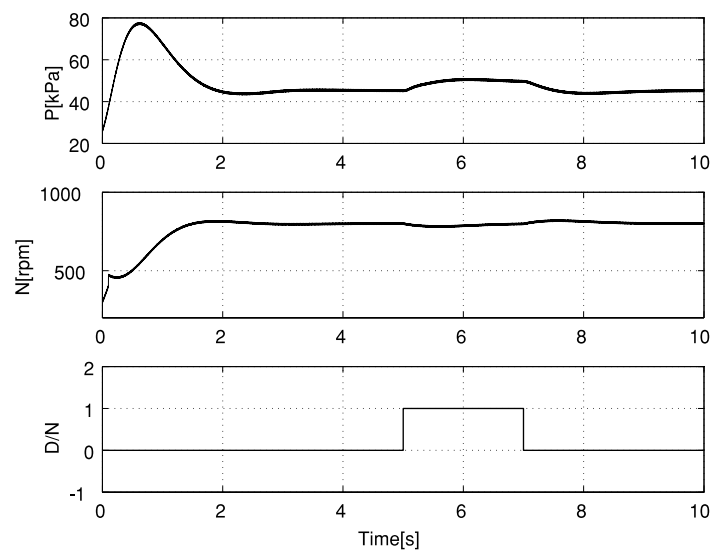

図 13 マニホールド内圧力, エンジン回転数と, $\mathrm{D} / \mathrm{N}$ スイッチ

Fig. 13. Manifold pressure, engine speed and $\mathrm{D} / \mathrm{N}$ swich.

およびスライディングモード制御は負荷外乱に対しても安 定に動作することについても確認された。

\section{5. まとめ}

本研究では電子制御スロットルサーボ系を含む自動車エ ンジンシ全体の非線形システムに対してモデリングを行う とともに, 非線形 VSS オブザーバを用いたスライディン グモード制御方法を提案し，エンジン回転数制御を行った。 エンジン回転数制御において MATLABによるシミュレー ションおよび実験を行った。シミュレーションおよび実験 結果から, 設計したVSS オブザーバおよびスライディング モード制御が安定に動作しており，本手法の有効性を確認 できた。

今後は, 燃料系を含むエンジンシステムのモデリング, パ ラメータ同定と, それに基づくエンジン制御系システムの 最適設計を行うとともに，実験的な検討も行っていく予定 
である。

(平成 19 年 10 月 7 日受付, 平成 20 年 4 月 12 日再受付)

\section{文献}

（1）特公 昭和 63-29099 (JP, B2)

(2) 特公 US006133643A, Oct.17, 2000

(3) S. Umerujan, S. Hyrret, and K. Nakano: "Identification and Robust Control of Electronic Controlled Throttle Systems", Trans. of SICE, Vol.39, No.12, pp.1150-1155 (2003) (in Japanese)

ウメルジャンサウット・ハイレットトフティ・中野和司：「電子制 御スロットルシステムの同定とロバスト制御」,計測自動制御学会論 文集, 39, 12, pp.1150-1155 (2003)

(4) R. Conatser, J. Wagner, S. Ganta, and I. Walker: "Diagnosis of Automotive Electronic Control Systems", Control Engineering Practice., Vol.8, No.6, pp.1-8 (2002)

(5) S-B. Choi and J.K. Hedrick: "Robust Throttle Control of Automotive Engines: Theory and Experiment", Trans. of the ASME., Jornal of Dynamic Systems, Meusurement and Control, Vol.118, pp.982-988 (1996)

(6) C. Rossi, A. Tilli, and A. Tonielli: "Robust Control of a Throttle Body for Drive by Wire Opening of Automotive Engines", IEEE Trans. on Control System Tech., Vol.8, No.6, pp.993-1002 (2000)

(7) M. Sommerville, C. Hatipoglu, and Ümit. Özgüner: "Switching Control of a Pneumatic Throttle Actuator", Control System Magazine, Vol.18, Issue 4, pp.81-87 (1998)

(8) G. Vachtsevanos, S.S. Farinwata, and D.K. Provolou: "Fuzzy Logic Control of an Automotive Engine", Control System Magazine, Vol.13, Issue 3, pp.62-68 (1993)

(9) S. Umerujan, A. Ishii, and B. Yasukawa: "Modeling and identification of an Automotive Engine Control Systems", Trans. of SICE, Vol.41, No.4, pp.373-379 (2005) (in Japanese) ウメルジャンサウット・石井光教・安川平八:「自動車用エンジン制 御システムのモデリングおよび同定」, 計測自動制御学会論文集, 41 4, pp.373-379 (2005)

(10) A. Gangopadhyay and P.H. Meckl: "Extracting Physical Parameters from System Identification of a Natural Gas Engine", IEEE Trans. on Control System Tech., Vol.9, No.3, pp.425-434 (2001)

(11) R.N.K. Loh and M. Lu: "Cranc-angle Domain Modeling and Optimal Tracking Control for Automotive Engine Idke Speed", IFAC Conf. on New Technologies for Computer Control, pp.389-394 (2001)

(12) K. Nonami and J. Den: Sloding-Mode Control—Design Theory of Nonlinear Robust Control Theory—, Corona Pub. (1994) (in Japanese)
野波健蔵・田 宏奇：スライディングモード制御一非線形ロバスト 制御の設計理論一, コロナ社 (1994)

(13) S. Umerujan, K. Higuchi, K. Nakano, and T. Matsuo: "Position Control of Electronic Controlled Throttle Systems by Sliding-Mode Control", Trans. of SICE, Vol.40, No.7, pp.770-776 (2004) (in Japanese)

ウメルジャンサウット・樋口幸治・中野和司・松尾孝美 :「スライ ディングモード制御による電子制御スロットルシステムの位置制御」, 計測自動制御学会論文集, 40, 7, pp.770-776 (2004)

(14) S. Umerujan, K.-B. Park, T. Hanamoto, and T. Tsuji: "Frictionless Control of Robot Arm with Sliding Mode Observer", Proceedings of the IEEE International Vehicle Electronics Conference, pp.61-65 (2001)

(15) S. Umerujan, T. Hanamoto, T. Tsuji, and N. Umeda: "Identification and Control of Non-linear System with Friction", Proceedings of the 6th IEEE International Workshop on Variable Structure Systems, pp.375-382 (2000)

(16) T. Tsuji, T. Hachino, R. Oguro, N. Umeda, and H. Takada: "A Control Design of Robotics Using the Genetic Algorithm", ISAROB, Artificial Life Robotics, Vol.2, pp.24-27 (1998)

ウメルジャン サウット（正員） 2001 年九州工業大学大学院工学

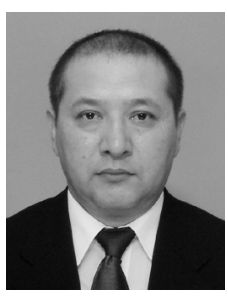
研究科電気工学専攻博士後期課程修了。同年 (株) ニッキ入社, 現在に至る。主として, 非線形シス テムのロバスト制御とその応用, システム同定, 柔 軟構造物の制振制御, エンジン制御, パワーエレ クトロニクスに関する研究に従事 (博士 (工学))。 計測自動制御学会, 日本機械学会, 自動車技術会, IEEE などの会員。

中 野 和 司 (正員) 1980 年九州大学大学院工学研究科電気

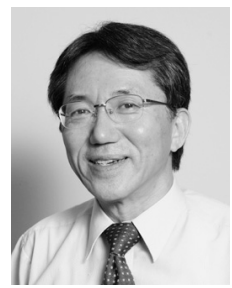
工学専攻博士課程単位修得退学。九州大学助手, 福岡工業大学助教授, 教授を経て, 1999 年より電 気通信大学教授。システム同定・制御に関する研 究に従事 (工学博士)。計測自動制御学会, シス テム制御情報学会, 電子情報通信学会, IEEE な どの会員。 